\title{
Serum magnesium levels in preterm labour in relation to socio-economic status
}

\author{
Shifali Anand, Rohini Jaggi*, Neerupham Bala
}

Department of Obstetrics and Gynaecology, Government Medical College, Jammu, Jammu and Kashmir, India

Received: 28 December 2021

Accepted: 10 January 2022

\author{
*Correspondence: \\ Dr. Rohini Jaggi, \\ E-mail: rohiniabhishekanand@gmail.com
}

Copyright: (c) the author(s), publisher and licensee Medip Academy. This is an open-access article distributed under the terms of the Creative Commons Attribution Non-Commercial License, which permits unrestricted non-commercial use, distribution, and reproduction in any medium, provided the original work is properly cited.

\begin{abstract}
Background: Serum magnesium level in pregnancy is a valuable tool to find out preterm onset of labour. In the asymptomatic group, greater surveillance and administration of steroids, tocolytics and transfer to a higher centre. In this study, low maternal serum magnesium level was associated with preterm labour. The values were also lower in women with low socio-economic status.

Methods: The subjects included 100 pregnant women with preterm labour (cases) between 28 and 37-week gestation (group A) and similar number of pregnant women with term labour (controls) between 37 and 40 weeks (group B). Inclusion criteria for cases was singleton pregnancy, painful uterine contractions more than two in 30 minutes, intact fetal membranes, cervical dilatation (at least $1 \mathrm{~cm}$ ) and effacement $(80 \%)$. Serum magnesium levels were done in both the groups. Patients were followed until delivery. Routine antenatal investigations were done. Serum levels of magnesium were estimated by Erba's semi auto-analyser.

Results: $62 \%$ patients in group A were from rural areas. More patients in group A (70\%) were from low socioeconomic class. More women in group A were anaemic (44\%). Mean value of hemoglobin in group A was $9.93 \mathrm{~g} / \mathrm{dl}$. More patients in group A had muscle cramps (89\%). VLBW (<1500 g) neonates were more in group A $(21 \%)$. Also, LBW (1500$2499 \mathrm{~g})$ neonates were more in group A $(60 \%)$. Mean neonatal birth weight in group A (1907.3 g) was less. Neonatal morbidity and mortality were observed significantly more in group A. Mean serum magnesium was less in group A.

Conclusions: Low maternal serum magnesium level is associated with preterm labour. Patients with preterm labour have significantly low serum magnesium level when compared with labour at term. The values were also lower in women with low socioeconomic status.
\end{abstract}

Keywords: Pre-term labour, Maternal serum magnesium, Term delivery, Socio-economic status

\section{INTRODUCTION}

Preterm labour is occurrence of regular uterine contractions and cervical changes in a woman with intact fetal membranes and gestational age <37 weeks. ${ }^{1}$ Uterine contraction without cervical change is also a marker of threatened preterm labour. ${ }^{2}$ Magnesium is the second important positively charged ion found within the cells of body. It acts as a cofactor in more than 300 enzyme reactions. It activates those enzymes and plays an important role in the nerve conduction and contractile response of smooth muscles. Pregnancy is marked by a state of relative hypomagnesaemia and varied hypomagnesaemia is observed in preterm labour. Hypomagnesaemia leads to neuromuscular hyperexcitability resulting in muscle cramps and uterine hyperactivity. $^{3}$

Magnesium plays an important role in pregnancy for the formation of new tissues, both maternal and fetal. Pregnant women require higher magnesium intake than the normal non-pregnant women of same age. Normal serum levels of magnesium in third trimester of pregnancy range from 1.1 to $2.2 \mathrm{mg} / \mathrm{dl} .^{2}$ Magnesium deficiency results in fatigue, confusion, irritability, weakness and hypertension, loss of appetite, insomnia, nausea, vomiting, diarrhoea, defect in 
nerve conduction and muscle contraction. Its deficiency during pregnancy is also associated with preterm labour, pre-eclampsia, small for gestational age (IUGR) foetus, leg cramps as well as sudden infant death syndrome. ${ }^{4}$

Estimation of serum magnesium levels in pregnancy may prove to be a valuable tool in the prediction of preterm onset of labour. This can help to provide greater antenatal surveillance in the asymptomatic group, and administration of steroids, tocolytics and transfer to a higher centre in those with symptoms of preterm labour. ${ }^{5}$ This study was conducted in a tertiary care hospital of north India to find association between serum magnesium levels and women with preterm labour, and to compare these values with those patients who had a term delivery.

\section{METHODS}

This observational case-control study was conducted for a period of one year in the postgraduate department of obstetrics and gynaecology, SMGS Hospital, Government Medical College, Jammu after due approval from Institutional Ethics Committee. The subjects included 100 pregnant women with preterm labour (cases) between 28and 37-weeks gestation (group A) and similar number of pregnant women with term labour (controls) between 37 and 40 weeks (group B). Inclusion criteria for cases was singleton pregnancy, painful uterine contractions more than two in 30 minutes, intact fetal membranes, cervical dilatation (at least $1 \mathrm{~cm}$ ) and effacement (80\%). Pregnant women with fibroid uterus, cervical incompetence/any uterine malformation, previous history of recurrent abortions/preterm delivery, with multiple pregnancy, ruptured membranes, placenta previa, known or detected fetal abnormality, polyhydramnios and significant medical/surgical history were excluded from the study. Controls were selected on the same day as that of cases by simple random sampling. Informed consent was taken from all the subjects. Study period was between September 2016 to August 2017.

All the patients were subjected to thorough history taking including socio-economic status, systemic and obstetric examination. Laboratory investigations were done as per hospital protocol. Serum magnesium levels were done in both the groups. Patients were followed until delivery. Routine antenatal investigations were done. In patients with preterm labour, following additional investigations were done in addition to the routine: USG for fetal wellbeing and cervical length, CRP. Maternal outcome included mode of delivery. Fetal outcomes included IUGR, AFD, birth weight, MAS and any neonatal complications like jaundice/respiratory distress/neonatal death/ IVH were noted. Serum levels of magnesium were estimated by Erba's semi auto-analyser.

All data collected was analyzed using computer software Microsoft excel and SPSS version 21.0 for Windows. Data was reported as mean \pm standard deviation and proportions as deemed appropriate for quantitative and qualitative variables respectively. The statistical difference in mean value between two groups was tested using unpaired ' $t$ ' test. The qualitative data was compared using Fisher's exact test/Chi-square test. ANOVA (analysis of variance) was also performed to evaluate statistical significance in more than two groups. A $p$ value of $<0.05$ was taken as significant. All p values reported were two-tailed.

\section{RESULTS}

In both, group A (cases) and group B (controls), majority of patients were in the age group of 21 to 30 years $(83 \%$ and $85 \%$ respectively), with mean age being comparable in both the groups (24.96 versus 25.04 years, $\mathrm{p}=0.88$ ). Mean serum magnesium level was found significantly less in patients with preterm labour $(1.10 \pm 0.40 \mathrm{mg} / \mathrm{dl})$ as compared to patients with term labour $(1.58 \pm 0.46 \mathrm{mg} / \mathrm{dl})$. $70 \%$ of patients in group A and 55\% in group B were from low socioeconomic class. $27 \%$ patients in group B were from rural areas, the difference being statistically significant $(\mathrm{p}<0.0001)$.

Majority of patients in both the groups were housewives (85\% and 90\%), difference being statistically not significant $(\mathrm{p}=0.39)$. More patients in group A $(70 \%)$ were from low socioeconomic class as compared to group B $(55 \%)$, difference being statistically significant $(\mathrm{p}=0.04)$. More women in group A were anaemic (44\%) as compared to group B (37\%). Similarly, more patients in group A had muscle cramps $(89 \%)$ as compared to group B $(51 \%)$, the difference being statistically significant $(\mathrm{p}<0.0001)$. VLBW (<1500 g) neonates were significantly $(\mathrm{p}=0.004)$ more in group A (21\%) as compared to group B (5\%). Also, LBW (1500-2499 g) neonates were significantly $(\mathrm{p}<0.0001)$ more in group A $(60 \%)$ as compared to group B (11\%). Mean neonatal birth weight in group A (1907.3 g) was significantly $(\mathrm{p}<0.0001)$ less as compared to that of group B (2723.6 g).

In group $A$, mean value of serum magnesium among gestational age groups 28-30, 31-33 and 34-37 weeks was found to be $1.13,1.11$ and $1.08 \mathrm{mg} / \mathrm{dl}$ respectively, the difference however was not significant $(\mathrm{p}=0.90)$.

Table 1: Group comparison for serum magnesium levels.

\begin{tabular}{|llll|}
\hline Serum magnesium level $(\mathrm{mg} / \mathrm{dl})$ & $\begin{array}{l}\text { Group A }(\mathrm{N}=\mathbf{1 0 0}) \\
\mathbf{N}(\%)\end{array}$ & $\begin{array}{l}\text { Group B }(\mathrm{N}=100) \\
\mathbf{N}(\%)\end{array}$ & $\begin{array}{l}\text { Statistical interpretation } \\
\text { (Chi-square test) }\end{array}$ \\
\hline $\mathbf{1 . 1}$ & $66(66.00)$ & $23(23.00)$ & $\chi^{2}=35.56 ; \mathrm{p}<0.0001^{*}$ \\
\hline $\mathbf{1 . 1 - 1 . 7 9}$ & $21(21.00)$ & $29(29.00)$ & $\chi^{2}=2.28 ; \mathrm{p}=0.13^{* *}$ \\
\hline$\geq \mathbf{1 . 8 0}$ & $13(13.00)$ & $48(48.00)$ & $\chi^{2}=23.72 ; \mathrm{p}<0.0001^{*}$ \\
\hline Total & 100 & 100 & - \\
\hline
\end{tabular}




\begin{tabular}{|llll|}
\hline Serum magnesium level (mg/dl) & $\begin{array}{l}\text { Group A }(\mathrm{N}=100) \\
\mathbf{N}(\%)\end{array}$ & $\begin{array}{l}\text { Group B }(\mathrm{N}=100) \\
\mathbf{N}(\%)\end{array}$ & $\begin{array}{l}\text { Statistical interpretation } \\
\text { (Chi-square test) }\end{array}$ \\
\hline $\begin{array}{l}\text { Mean } \pm \text { standard deviation } \\
\text { (range) (mg/dl) }\end{array}$ & $1.10 \pm 0.40(0.7-2.1)$ & $1.58 \pm 0.46(0.7-2.2)$ \\
\hline $\begin{array}{l}\text { Statistical interpretation } \\
\text { (unpaired t test) }\end{array}$ & $\mathrm{t}=7.38 ; \mathrm{p}<0.0001 ;$ highly significant \\
\hline
\end{tabular}

Note: *Highly significant; **Not significant.

Table 2: Group comparison for socioeconomic class.

\begin{tabular}{|llll|}
\hline Socio-economic class & $\begin{array}{l}\text { Group A }(\mathrm{N}=\mathbf{1 0 0}) \\
\mathbf{N}(\%)\end{array}$ & $\begin{array}{l}\text { Group B }(\mathrm{N}=\mathbf{1 0 0}) \\
\mathbf{N}(\%)\end{array}$ & $\begin{array}{l}\text { Statistical interpretation } \\
\text { (Fisher's exact test) }\end{array}$ \\
\hline Low & $70(70.00)$ & $55(55.00)$ & P=0.04; \\
\hline Middle & $22(22.00)$ & $32(32.00)$ & significant \\
\hline High & $8(8.00)$ & $13(13.00)$ & - \\
\hline Total & 100 & 100 & - \\
\hline
\end{tabular}

Table 3: Relationship of socio-economic status with mean serum magnesium level.

\begin{tabular}{|c|c|c|c|c|c|}
\hline \multirow{3}{*}{ Socio-economic status } & \multirow{2}{*}{\multicolumn{2}{|c|}{$\begin{array}{l}\text { Serum magnesium level } \\
\text { Group A }\end{array}$}} & \multirow{2}{*}{\multicolumn{2}{|c|}{$\begin{array}{l}\text { Statistical interpretation } \\
\text { (Unpaired t test) } \\
\text { Group B }\end{array}$}} & \multirow{3}{*}{$\begin{array}{l}\text { Statistical interpretation } \\
\text { (Unpaired } \mathrm{t} \text { test) }\end{array}$} \\
\hline & & & & & \\
\hline & $\mathbf{N}$ & $\begin{array}{l}\text { Mean } \pm \text { SD } \\
(\mathrm{mg} / \mathrm{dl})\end{array}$ & $\mathbf{N}$ & $\begin{array}{l}\text { Mean } \pm \text { SD } \\
(\mathrm{mg} / \mathrm{dl})\end{array}$ & \\
\hline Low & 70 & $1.08 \pm 0.44$ & 55 & $1.3 \pm 0.47$ & $\mathrm{t}=0.96 ; \mathrm{p}=0.35^{* *}$ \\
\hline Middle & 22 & $1.15 \pm 0.43$ & 32 & $1.62 \pm 0.43$ & $\mathrm{t}=5.52 ; \mathrm{p}<0.0001^{*}$ \\
\hline High & 8 & $1.04 \pm 0.47$ & 13 & $1.51 \pm 0.50$ & $\mathrm{t}=3.89 ; \mathrm{p}=0.0002^{*}$ \\
\hline
\end{tabular}

Table 4: Intra-group comparison of preterm labour gestational age with mean serum magnesium level.

\begin{tabular}{|c|c|c|}
\hline Gestational age (weeks) & $\begin{array}{l}\text { Serum magnesium level } \\
\text { Group A (mg/dl) }\end{array}$ & $\begin{array}{l}\text { Statistical interpretation (One-way } \\
\text { ANOVA) }\end{array}$ \\
\hline $28-30(\mathrm{~N}=11)$ & $1.04 \pm 0.14$ & \multirow{3}{*}{$\mathrm{F}=3.44 ; \mathrm{p}=0.03$; significant } \\
\hline $31-33(\mathrm{~N}=34)$ & $0.97 \pm 0.33$ & \\
\hline $34-37(\mathrm{~N}=55)$ & $1.22 \pm 0.52$ & \\
\hline
\end{tabular}

\section{DISCUSSION}

Magnesium deficiency in pregnancy is likely to cause perinatal complications which may last throughout life. In the present study, $74 \%$ patients in preterm labour group were primigravida, which is in accordance with the study of Khani et al $(75 \%) .{ }^{10}$ Mean gestational period in our study was 33.69 weeks in preterm labour group and 37.97 weeks in term group, the difference being statistically significant $(\mathrm{p}<0.0001)$. Similarly, Begum and Das et al found mean gestational age of 33.03 weeks and 38.95 weeks in patients with preterm and term labour. ${ }^{5}$

In the present study, mean serum magnesium level was $1.10 \pm 0.44 \mathrm{mg} / \mathrm{dl}$ in patients with preterm labour while it was $1.58 \pm 0.46 \mathrm{mg} / \mathrm{dl}$ in patients with term labour, the difference being statistically significant. Sixty-six percent patients with preterm labour had low serum magnesium level $(<1.1 \mathrm{mg} / \mathrm{dl})$ (Table 1$)$. This finding showed that preterm labour was associated with low serum magnesium level. Preterm birth is the single major cause associated with neonatal morbidity and mortality in both developing and developed world.
This result is in accordance with the study of Shahid et al in which significantly more patients with preterm labour $(60 \%)$ had serum magnesium level $<1.9 \mathrm{mg} / \mathrm{dl} .{ }^{6}$ Bhat et al found that patients in preterm labour group had a significantly depressed mean serum magnesium level as compared to normal pregnancy $(1.34 \mathrm{meq} / 1 \mathrm{vs} 1.87 \mathrm{meq} / \mathrm{l}$; $\mathrm{p}<0.001){ }^{7}$ Mahmoud and Jenabi et al also found positive association between maternal serum magnesium levels and preterm labour. ${ }^{8,9}$

Magnesium nutrient density is less in the diet ingested by low income group women and in those who are vegetarian. In the present study, $70 \%, 22 \%$ and $8 \%$ patients with preterm labour and $55 \%, 32 \%$ and $13 \%$ with term labour belonged to low, middle and high socioeconomic class respectively, the difference being statistically significant $(\mathrm{p}=0.04)$ (Table 2). Bhat et al found patients with preterm labour belonging to low socio-economic class were significantly higher than the middle and higher socioeconomic classes $(58 \%$ in preterm labour patients and $45 \%$ in term, $\mathrm{p}<0.05) .{ }^{7}$ Mahmoud et al also found that in preterm labour group lower socio-economic class was 
significantly higher than the middle and upper socioeconomic classes. ${ }^{8}$ In our study $62 \%$ patients with preterm labour and $27 \%$ patients with term labour were from rural areas, the difference being statistically significant $(p<0.0001)$. The difference was due to high rate of referrals of preterm pregnancies to our hospital (tertiary health care centre) from peripheral rural areas where NICU facilities were not available. Similarly, Kumar et al also found $65 \%$ of patients with preterm labour were from rural areas. $^{10}$

In our study low birth weight neonates were significantly more in patients with preterm labour with percentage of $60 \%$ and $11 \%$ in patients with term labour. Similarly, Khani et al reported that low birth weight neonates were $80 \%$ in patients with preterm labour. ${ }^{11}$ In a study conducted by Shaikh et al IUGR was significantly higher $41.3 \%$ patients with preterm labour $(\mathrm{p}<0.001) .{ }^{12}$

In both group A and B, low socio - economic class patients had lower serum magnesium levels as compared to middle and higher class with values of $1.08 \pm 0.44$ and $1.3 \pm 0.47$ $\mathrm{mg} / \mathrm{dl}$ respectively (Table 3 ). Socio-economic status affected serum magnesium levels significantly in term as well as preterm group, the values being lowest for women belonging to low socioeconomic status. These observations are similar to those reported by Sharma et al, Franz et al and Potnis et al. ${ }^{13-15}$ Patients belonging to low socioeconomic classes have stressful lifestyle, inaccessible medical care and diet deficient in micronutrients including magnesium. In our study mean value of serum magnesium was $<1.1 \mathrm{mg} / \mathrm{dl}$ in 34-37 weeks gestational age group. Mean levels of serum magnesium among gestational age groups 28-30, 31-33 and 34-37 weeks was found to be $1.13 \pm 0.20,1.11 \pm 0.39$ and $1.08 \pm 0.44 \mathrm{mg} / \mathrm{dl}$ respectively (Table 4). Bhat et al found mean serum magnesium level of $1.37 \pm 0.055, \quad 1.35 \pm 0.065$ and $1.31 \pm 0.060 \mathrm{mg} / \mathrm{dl}$ respectively in preterm gestational age groups 28-30 weeks, 31-33 weeks and 34-36 weeks with lowest levels at 34-36 weeks period of gestation. ${ }^{7}$ Mahmoud et al found that in 28-30 weeks gestational age group level was $1.843 \pm 0.70 \mathrm{mg} / \mathrm{dl}, 31-33$ weeks $1.309 \pm 0.369 \mathrm{mg} / \mathrm{dl}$ and 34-36 weeks $1.23 \pm 0.28 \mathrm{mg} / \mathrm{dl}{ }^{8}{ }^{8}$ With these studies it was found that magnesium level decreases with increasing gestational which may be due to physiological hemodilution in pregnancy contributing to the onset of preterm labour. Decrease in magnesium plays an important role in physiology of parturition. Hypomagnesemia causes inhibition of adenyl cyclase with resultant increase in cytoplasmic calcium levels. Calcium by its action on calmodulin activation brings about uterine contraction, while magnesium prevents uterine contractions. Magnesium level may affect the blood flow through the uterus and may contribute towards lysosome stabilization. Hypomagnesemia, therefore, may be either a causative factor or simply reflect the process involved with the development of uterine irritability in preterm labour.

\section{CONCLUSION}

In this study, low maternal serum magnesium level was associated with preterm labour and patients with low socio-ecomic status had lower levels of serum magnesium as compared to middle and high socio-economic status. Patients with preterm labour had significantly low serum magnesium level when compared with labour at term. This study recommends that important steps should be taken to prevent and treat magnesium deficiency as it has direct implication on mother as well as fetus.

Funding: No funding sources

Conflict of interest: None declared

Ethical approval: The study was approved by the Institutional Ethics Committee

\section{REFERENCES}

1. Arias F, Bhide A, Arulkumaran S, Damania K, Daftary S. Preterm parturition syndrome. Practical Guide to High Risk Pregnancy and Delivery. 3rd ed. India: Elsevier; 2008: 193-204.

2. Cunningham FG, Leveno KJ, Bloom SL, Spong CY, Dashe JS, Hoffman BL, et al. Preterm labour. Williams Obstetrics. 24th ed. New York, NY: McGraw-Hill; 2014: 829-861.

3. Hantoushzadeh S, Jafarabadi M, Khazardoust S. Serum magnesium levels, muscle cramps, and preterm labor. Int J Gynaecol Obstet. 2007;98(2):153-4.

4. Durlach J. New data on the importance of gestational Mg deficiency. J Am Coll Nutr. 2004;23(6):694-700.

5. Durlach J. New data on the importance of gestational Mg deficiency. J Am Coll Nutr. 2004;23(6):694-700.

6. Shahid AR, Hosna AU, Tahmina HZ. Hypomagnesemia in pregnancy: A predictor of preterm labour. J Dhaka Med Coll. 2010;19(1):51-7.

7. Bhat S, Waheed A, Chisti T, Habib H. Hypomagnesemia as a marker for preterm labour and its association with socioeconomic status. J Invest Biochem. 2012;1(1):24-30.

8. Mahmoud SA, Saleh IM, Khalaf HH. The correlation between maternal hypomagnesemia and preterm labour. Int J Reprod Contracept Gynaecol. 2016;5(8):2571-5.

9. Jenabi E, Poorolajal J, Fereidooni B, Asltoghiri M, Hejrati P. The association between maternal serum magnesium level and pregnancy outcomes. J Postgrad Med Inst. 2017;31(1):77-81.

10. Kumar AN. Correlation of serum magnesium level with increase in parity and comparison among rural and urban pregnant women. Int J Cur Bio Med Sci. 2012;2(1):185-7.

11. Khani S, Shokrzadeh M, Karamoddini PK, Shahmohammadi S. The relationship between maternal serum magnesium level and preterm birth. Pak J Biol Sci. 2010;13(7):335-9.

12. Shaikh K, Das CM, Baloch GH, Abbas T, Fazlani K, Jaffery MH, et al. Magnesium associated 
complications in pregnant women. World Appl Sci J. 2012;17(9):1074-78.

13. Sharma A, Kharb S, Vineeta, Gulati N. Serum magnesium levels in preterm labour in relation to socioeconomic status. Indian $\mathrm{J}$ Clin Biochem. 1998;13(2):123-5.

14. Franz KB. Magnesium intake during pregnancy. Magnesium. 1987;6(1):18-27.
15. Potnis AV, Patel PV, Purandare SN. Magnesium, the ignored, element during pregnancy. J Obstet Gynec. India. 1977;27:343-5.

Cite this article as: Anand S, Jaggi R, Bala N. Serum magnesium levels in preterm labour in relation to socio- economic status. Int J Reprod Contracept Obstet Gynecol 2022;11:552-6. 